\title{
Chapter 10 \\ Establishment and management of suitable species in dairy pastures
}

\author{
E.R. Thorn', N.A. Thomson* \\ and D.G. Clayton' \\ ${ }^{1}$ Ruakura Agricultural Research Centre, MAF, Hamilton \\ ${ }^{2}$ Taranaki Agricultural Research Station, MAF, Normanby
}

\section{INTRODUCTION}

For the success of a new dairy pasture, species and cultivars must be selected to counter the limitations to dairying of existing pasture. After successful establishment, the subsequent management of the pasture must ensure its full potential is expressed. Pasture establishment is a costly operation $(\$ 300-500 /$ ha $)$ with some element of risk, caused by unpredictable climatic conditions, irrespective of the level of technical expertise adopted.

Dairy pastures may need renewal because of low soil fertility, poor drainage, presence of insect pests, summer drought, management factors such as undergrazing or overgrazing and winter pugging of soil surfaces and, on highly stocked farms, cow grazing behaviour. 'Pulling' of pasture plants is common in autumn, and continual hard grazing of dung-free areas of the paddock and lax grazing of the remainder occurs.

Definitive information is not available on the critical requirements for the establishment and management of recently released pasture species but through failures and successes in trial and paddock sowings it is possible to develop a "best bets" approach.

\section{EST A B L ISH MENT}

Pasture establishment methods include full cultivation with drilling, partial cultivation and renovation with either oversowing or overdrilling.

\section{Full cultivation}

Traditional cultivation and tillage methods (ploughing, discing, rollatilling, levelling) to obtain a fine, firm, weedfree seedbed ensure the sown species have the maximum opportunity, with adequate moisture, to establish and express their full growth potential. Dairy farmers are reluctant to use full cultivation methods because in general:

1. they lack expertise. Most sharemilkers are not interested in the long-term benefits of this method of establishment since they are employed on short-term contracts (3 years). There is therefore no incentive to obtain maximum benefits from good seedbed preparation.

2. they lack appropriate equipment.

3. small paddock sizes and land contour often do not lend themselves to ploughing.

4. on highly stocked farms, the costs of the time required for ploughing and cultivation, and for the new pasture to reach high production levels are prohibitive.

For these reasons dairy farmers would rather use renovation procedures (oversowing or overdrilling) possibly in conjunction with partial cultivation (surface discing or ripping).

Minimum tillage techniques using herbicide prior to cultivation along with tillage machines like rollatillers have produced good seedbeds in a short time on volcanic ash soils. On the heavier clay soils seedbed preparation would take longer using these techniques.

Drilling is recommended for sowing of all seeds, except Matua prairie grass which has long seeds (20 $\mathrm{mm}$ ) causing bridging in seed boxes. Seed flow is improved by mixing with untreated sawdust ( $50 / 50$, w/w) and sowing through the fertiliser box. Alternatively, successful establishment can be obtained by broadcasting then harrowing to ensure most seeds are partially buried and have a chance of germinating and establishing.

\section{Partial cultivation}

Partial cultivation is recommended in preparation for oversowing or overdrilling, when soil surfaces are too hard for drilling or when they have been sealed by pugging or when sod-bound, for example paspalum dominant, pastures exist. 


\section{Renovation}

Two methods are used to renovate pastures:

1. Oversowing - the broadcasting of seed by mechanical or manual means over the pasture surface with no attempt at precise placement.

2. Overdrilling - the drilling of seed into soil without prior cultivation of the established pasture.

Success of renovation procedures as a means of establishing new species depends on many factors the most important being to minimise competition for light, water and nutrients between the introduced and resident species, and to control any pests likely to attack seeds or seedlings.

Competition. Severe grazing of pastures to be renovated is recommended. This management is aimed at minimising early competition for light between young seedlings and established plants. Drilling too deeply ( $>20 \mathrm{~mm}$ soil depth) will also weaken seedlings by restricting their ability to grow into a satisfactory light environment. Subsequent management procedures such as regular hard grazings of young (up to 6 month old) pasture and the use of herbicide applications at or before drilling require testing as practical methods of controlling competition from resident plants.

In some cases of overdrilling there have been short-term (about 12 months) improvements in pasture cover and animal performance. However there is little benefit to be obtained in terms of annual dry matter production from overdrilling of grasses or legumes without controlling the growth or resident species or using herbicide band widths of more than $50 \mathrm{~mm}$. In the absence of perennial weeds (e.g. paspalum, Californian thistles, docks, yarrow) paraquat $(5-6 / / \mathrm{ha})$ or mixtures of paraquat and diquat (3l/ha) herbicides can be used, without damaging resident clovers. When perennial weeds are to be controlled, glyphosate (4-6l/ha) herbicide must be used although severe inhibition of resident clover growth will occur for about 12 months after spraying. To obtain improved establishment of overdrilled seedlings and greater long-term production benefits, it is necessary to kill a high proportion of the resident species with blanket application of broad spectrum herbicides. If growth of resident species has been markedly reduced by overgrazing during drought, severe insect attack or winter pugging, the new pastures can be rapidly established by overdrilling provided the limiting factor is controlled.

Pests. Grass grub numbers above a paddock average of 10 grubs/spade should be controlled by drilling insecticide (Dasanit or Miral, $1 \mathrm{~kg}$ a.i./ha) mixed with the seed. The possibility of predation of autumn oversown grass and clover seed by black field crickets should not be overlooked, especially in Northland, while slug control for autumn sowings is less important than for spring sowings. All grass species are susceptible to Argentine stem weevil damage especially when newly sown. Recently harvested (no more than 1 year old) ryegrass seedlines with high levels of Acremonium endophyte fungus should be sown to provide some protection against stem weevil damage.

Other aspects which must be considered when renewing or renovating pastures are coulter type, time of sowing, seed rates, sowing depth and postemergence management.

Coulter type. Extensive trial work on drill coulters, shows moisture retention for seed germination is better for a new chisel coulter (with sub-surface wings) and bar harrow combination, than for the commonly used triple disc coulter and bar harrow. Where soil moisture is adequate, however, little difference is noted in seedling emergence due to coulter type.

Time of sowing. Cultivation or renovation of dairy pastures usually takes place in autumn (MarchMay) when the farmer has time to complete the operations. Renovation in autumn rather than spring is appropriate since the maximum growth period for the resident species is avoided and conditions are still suitable for germination and growth of the introduced species. Autumn cultivation is favoured because farmers believe that pasture lost over autumn is of less value than pasture lost over early spring. However, this is not necessarily true, since autumn pasture surpluses rarely occur in intensive dairying systems and loss of grazing area at this time will reduce lactation length and could seriously affect winter and early spring management.

Autumn sowing is preferable on heavy soil types since for most spring sowings it would be difficult (unless direct drilling) to get cultivation over early enough to allow establishment before the onset of dry summer weather.

Autumn sowing is recommended for the faster establishing and winter active grasses (ryegrass, prairie grass, phalaris) while slower establishing less winter active (cocksfoot, tall fescue) should be sown in spring. If spring sowings are made, failure may result from early summer drought. This is less likely in Taranaki where water deficits do not normally occur until February than in the Waikato where water deficits usually occur in January.

Autumn sowings of slower establishing grasses can be adversely affected by competition from Poa annua which is difficult and costly to control. With 
spring sown grasses, selective herbicides (MCPB and 2,4-DB) can be used to control flatweeds.

Both white and red clovers can be established in autumn or spring with spring sowings producing a better balanced pasture over the succeeding 12 months. The problem of cocksfoot and tall fescue pastures being subject to clover dominance in the first year after sowing is minimised by sowing in spring. However, spring sowing ryegrasses with clover results in the rapidly establishing Nui and Ellett ryegrasses dominating the less vigorous clovers.

Seed rates. Recommended seed rates for grasses in grass/clover mixtures vary with species from 20-35 $\mathrm{kg} / \mathrm{ha}$ with about $3-6 \mathrm{~kg} / \mathrm{ha}$ of clover seed included (similar to rates being used). There is a tendency towards increasing use of mixtures of grasses and legumes with a decline in the drilling of single grass species except in renovation operations. Seed rates of $10-15 \mathrm{~kg} / \mathrm{ha}$ are recommended for single grass species (somewhat higher than rates commonly used). The tendency for high seeding rates to be used in practice probably reflects farmers lack of confidence in the ability of species to establish under their particular farm circumstances, thus extra seed is sown in an attempt to cover for any deficiences in cultivation or renovation practices.

Seed quality. Farmers should insist on sighting the Seed Analysis Certificate to ensure they are purchasing (certified seed with high purity and germination percentage. Seed rates should be adjusted so the recommended rate of viable seed is sown. There is a need for seed merchants to constantly inform their staff of the pertinent agronomic characteristics of newly released species and for farmers to sow good quality seed. They should insist on receiving appropriate documentation on seed quality for every seedline purchased.

Depth of sowing. Better establishment of all grasses and legumes is obtained with drilling than with broadcasting of seed. The objective with drilling is to place the seed $10-15 \mathrm{~mm}$ beneath the soil surface. If sown too deep ( $>20 \mathrm{~mm})$, the growth of slower establishing species will be impaired or, if sown too shallow, the seed may have insufficient moisture to germinate.

\section{POST-EMERGENCE MANAGEMENT}

\section{During establishment}

For the rapidly establishing grasses the objective of management is to encourage clover growth by minimising grass competition. Frequent and intense grazing over the first spring following autumn sowing will therefore by necessary. This can be more readily achieved on highly stocked farms.
Frequent and intense grazing following emergence of seedlings of rapidly establishing species is appropriate but in practice farmers are reluctant to allow grazing of young seedlings for about 2-3 months from sowing. The vigour of Nui and Ellett ryegrasses in the first spring following autumn sowing is exceptional, and it can be difficult to maintain sufficient grazing pressure to achieve a desirable balance of ryegrass and clover. Preliminary indications are that G18 (a large-leaved white clover, see chapter 9) establishes better than Pitau when sown with Nui or Ellett ryegrass. It is also necessary to minimise competition between introduced and resident species during the winter/spring following autumn sowing, so that sufficient new seedlings grow large enough (20-30 tillers/plant) to be able to survive additional climatic and management stresses during summer. It is not known whether regular hard grazing of renovated pastures would achieve this aim.

Grazing management for the slower establishing grasses is less difficult than for ryegrass. Management does not have to be as intensive as for ryegrass since the objective is to encourage grass growth in preference to clovers. To achieve this a longer grazing interval and laxer grazings will be necessary. However the establishment of tall fescue and cocksfoot pastures in Taranaki has been favoured by a long interval (30 days) between intensive rather than lax grazings. Under lax grazing, clumps develop and overgrazing occurs on the previously grazed areas leading to poor establishment. Mowing in combination with grazing has proved to be beneficial to maintaining a more even and relatively intense defoliation over the establishment period. In the Waikato, mowing is recommended as the first defoliation of spring sown Roa tall fescue.

\section{Post-establishment}

Once the pasture is established the objective is to manage it so as to produce the maximum return of milkfat and milk protein. Animal performance is affected both by the amount and quality of pasture available and these can be influenced by grazing management.

The use of new ryegrass cultivars such as Nui and Ellett will improve feed production and extend lactation since these cultivars recover quicker after summer drought than older cultivars like Ruanui. Once established, Matua prairie grass improves late winter/early spring as well as summer/autumn pasture production but this requires experimental verification under dairy grazing. G18 white clover has better winter production than does Pitau or Huia 
but this again has not been tested under intensive dairy grazing.

The following are guidelines for the management of ryegrass pastures for dairying. During lactation (August-April), a residual herbage mass of $1500-2000 \mathrm{~kg} \mathrm{DM} / \mathrm{ha}$ is recommended to maintain an adequate intake. If grazing is below this critical level, intake and subsequent regrowth may be affected. If more than about $2000 \mathrm{~kg} \mathrm{DM} / \mathrm{ha}$ remains after grazing then the quality of pasture offered at subsequent grazings will decline. The quality of pasture may also decline (especially in late spring and summer) at high herbage mass levels.

During winter, all paddocks should be block grazed once between drying off and calving. The quality of pasture offered to dry cows in winter is not 'as critical to animal performance as during lactation but allowing the herbage mass before grazing to exceed $4000 \mathrm{~kg} \mathrm{DM} / \mathrm{ha}$ or grazing below $1000 \mathrm{~kg}$ $\mathrm{DM} / \mathrm{ha}$ will inhibit regrowth. Pugging pastures will also seriously restrict pasture growth for many months subsequently and should be avoided. On light soil, on-off grazing, offering the cows 2-3 times the normal daily break, and feeding out higher than normal amounts of supplements on very wet days are practical ways of overcoming serious pugging damage. On the heavier clay soils, supplements may be fed to stock on races or feeding pads during excessively wet periods.

There is no information available for dairy systems to suggest that the grazing of other than ryegrass dominant pastures over lactation should be different. However, for pastures based on Matua prairie grass or Roa tall fescue the interval between grazing should be increased to $30-40$ days. This can be done without any decline in feed quality. The intensity of grazing can be maintained without depressing regrowth. In winter two lax grazings for phalaris, tall fescue and prairie grass are recommended to minimise pugging damage and maximise pasture growth

\section{SUMMARY}

1. The introduction of alternative species to tyegrass/ white clover. the major species sown for dairy pasture, is only likely to benefit farmers already achieving high tevels of management expertise Low producing farmers should ain to improve their pasture utilisation before introducing alternative species.

2. The rate of adoption for newly introduced species for dairy pastures is s low in part due to the lack of precise information on their establishment, persistency and managentent requirements to improve dairy prodiction.

3. Unless the farmer tecognises the reasons for the detertoration of the old pasture and the requirements of the new spectes, the full potential of these species will not be realised.

4. Competition from the resident species must be controlled for up 10 6 months after sowing.

S. The fast establishing ryegrasses should be sown in antumn to allow betrer dover establishment.

6. Tor the slower establishing grasses (cocksfoot, tall fescue), carly spring sowing (September/October) into cultivated ground is recommended.

7. 10 prevent dover dominanee in the frestevear after sowing, grazings should be intensive but at a 25. 30 day interval over the first 6 months.

8. Thorough long term testing of new species with potential for dairying must be carried out under dairy cow grazing. At present, definitive data on the contribution to dairy production of new species are not available.

\section{FURTHER READING}

Baker C.J. 1980. Renovation of pastures. Proceedings of the Ruakura farmers' conference 32, 53-61.

Charlton J.F.L., Thom E.R. 1984. Establishment and persistence of new herbage species and cultivars. New Zealand Journal of Agricultural Science 18, 130-135.

Donald C.M. 1963. Competition among crop and pasture plants. Advances in Agronomy 15, 1-118.

East R. 1984. Insect pest control in dairy pastures. Proceedings of the Ruakura farmers' conference 36, 8-12.

Miller G.D. 1973. Successful undersowing at Waimate West. pp. 30-33. In: Drummond D.C., Rolston S. J., Wilson G.F. editors. Dairy farming annual. Massey University.

Robinson G.S., Cross M.W. 1960. Improvement of some New Zealand grassland by oversowing and overdrilling. pr $_{o c}$ eedings of VIII International Grassland Congress, Reading. pp. 402-405.

Sangakkara R., Roberts E., Watkin B.R. 1982. Grass species used and pasture establishment practices in central New Zealand. New Zealand Journal of experimental Agriculture 10, 359-364. 


\section{Discussion}

\section{PART V - NORTH ISLAND DAIRYING}

Q How can farmers identify high endophyte ryegrass seedlines?

A. Seed testing can indicate endophyte, but it is difficult and costly.

Viability of endophyte is sensitive to storage conditions and after 1 year seed has an unreliable endophyte level. An endophyte test would not be valid or useful if it was older than 3 months. If farmers want high endophyte lines, then they should purchase and sow freshly harvested seed. Endophyte levels drop with storage.

Q. How important is endophyte in NorthIsland dairying?

A. Farmers would prefer a persistent ryegrass pastiure (i.e. high endophytej and accept the associated animal health problems (e.g. mild staggers in calves).

The feeding deterrent involved in argentine stem weevil resistance in high endophyte ryegrass is distinct from the toxin that causes ryegrass staggers. There is the potential to select/breed for insect resistance and eliminate the staggers problems.

Q. What is the relative impact of insect attack on herbage production and depressed animal performance due to endophyte?

A. It must be remembered that research into the effects of endophyte on animal production is in its infancy and at present there is too much extrapolation from the few results available that is just speculation.

Q. How readily available is a purity and germination $(P \& G)$ certificate to farmers?

A The $\mathrm{P} \& \mathrm{G}$ of lines that make up a ready-made seed mix are often difficult to trace, but they are readily available for separate lines of purchased cultivars, and should be asked for.

Q. How many dairy farmers are at the utilization/production level that can benefit from extensive use of new cultivars?

A. In the Waikato, until farmers are producing 500 $\mathrm{kg}$ milk fat/ha, then they are not using the potential of the existing pasture production. Where pastures are run out (through, for example, insect damage or pugging), there is the opportunity to use new cultivars. Regular renovation for these reasons leads to most new cultivar 'usage.

Q. How would Matua prairie grass be used by dairying?

A. Being erect in growth Kara is suited to hay production, whereas the more prostrate Wana is more suited to grazing. Wana has been aggressive and productive in mixed pastures, but animal performance has not been as good as expected.

(See also Part III - Cultivatable Summer-Dry East Coast for discussion on endophyte). 